\title{
High Repulsion Permanent Magnet
}

Researcher and inventor: Umer Farooq

Note: This paper is continuation of "Paper 1: Basic research; Emerging of unexpected extra efficiency". The reader should read Paper 1 before reading this paper.

\section{Abstract}

Basic experiments that were described in the paper 'Basic research; emerging of extra efficiency' showed that at higher current, efficiency of a magnetic interaction increases substantially. However, it is not always possible using of higher current level. To reduce balanced force and to get extra efficiency at lower current a thorough research was conducted.

During the research a new kind of permanent magnet emerged. I have named this kind of permanent magnet as High Repulsion/ permeable permanent magnet. Making process of this magnet is simple but function of this magnet is very important. It provides significantly more efficiency than ordinary permanent magnet at lower current levels.

A piece of non -magnetized material was added to the interacting surface of a permanent magnet, then the magnet was interacted with the same electromagnet that was interacted with an ordinary permanent magnet. Addition of permeability to a permanent magnet provided marvelous results.

Permeability- added permanent magnet used lower input and provided stronger output in comparison with ordinary permanent magnet.

\section{Description}

\section{$B$ lines of a permeable permanent magnet}

(To avoid unnecessary effort, some suitable images were taken from internet). 


\section{Function of iron}

- Usually B lines of a permanent magnet emit from surface, but when a piece of iron is added to a permanent magnet, $B$ lines emit from all sides of the iron piece.

- Figure is below given.

\section{Figure: 1}

$B$ lines are emanating from sides

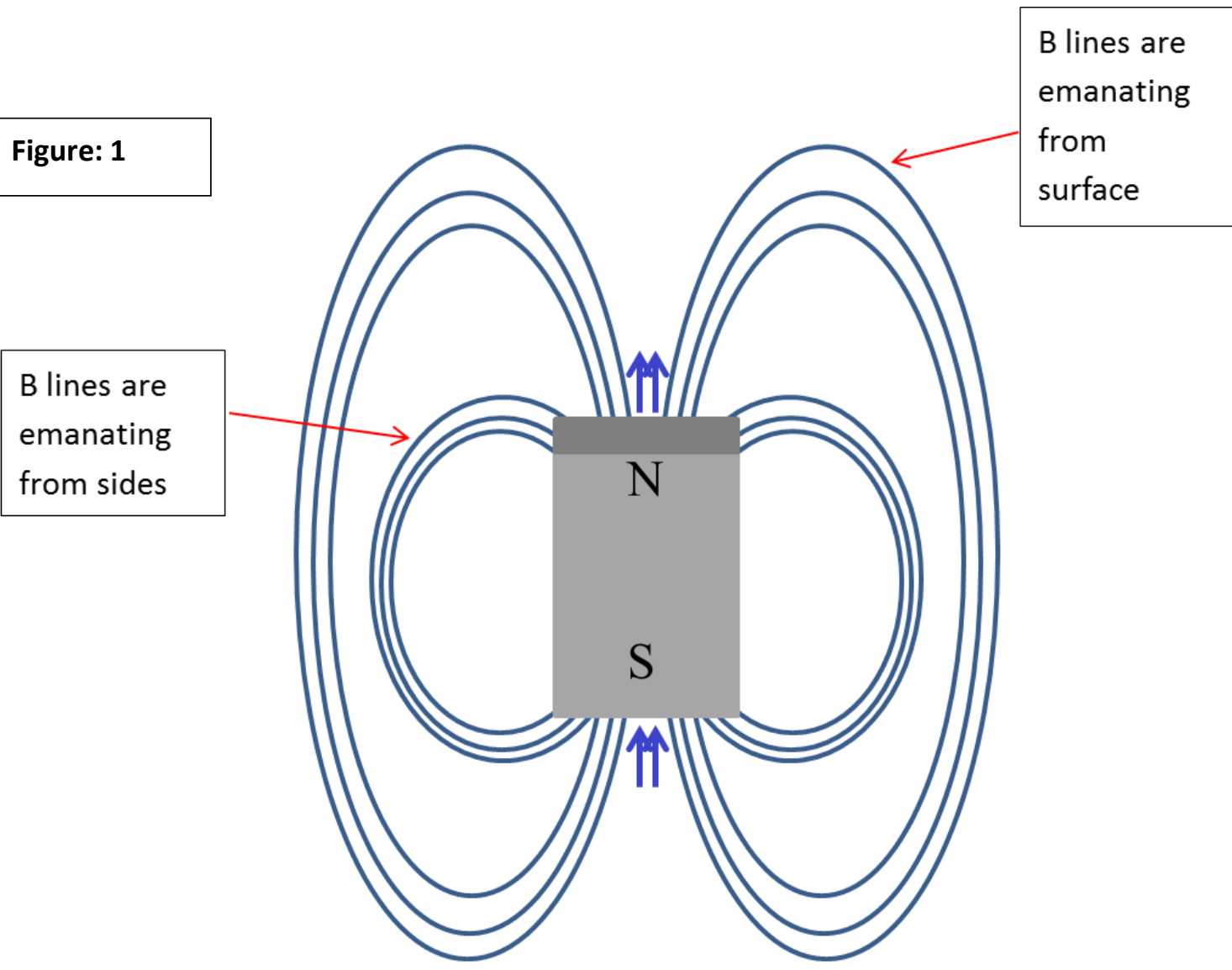

$B$ lines are emanating from surface

Note: $B$ lines emanate from all sides of iron, divided evenly. This figure has been given only to signify two basic directions of emanation of $B$ lines. 


\section{B lines of a permeable permanent magnet}

- Pattern of $B$ lines of a permeable permanent magnet is different than that of an ordinary permanent magnet.

- Some of the B lines emit from sides and some of the B lines emit from surface of iron piece.

- So, B lines of permeable permanent magnet make two sets. B lines emitting from sides make inner set. B lines emitting from surface make outer set.

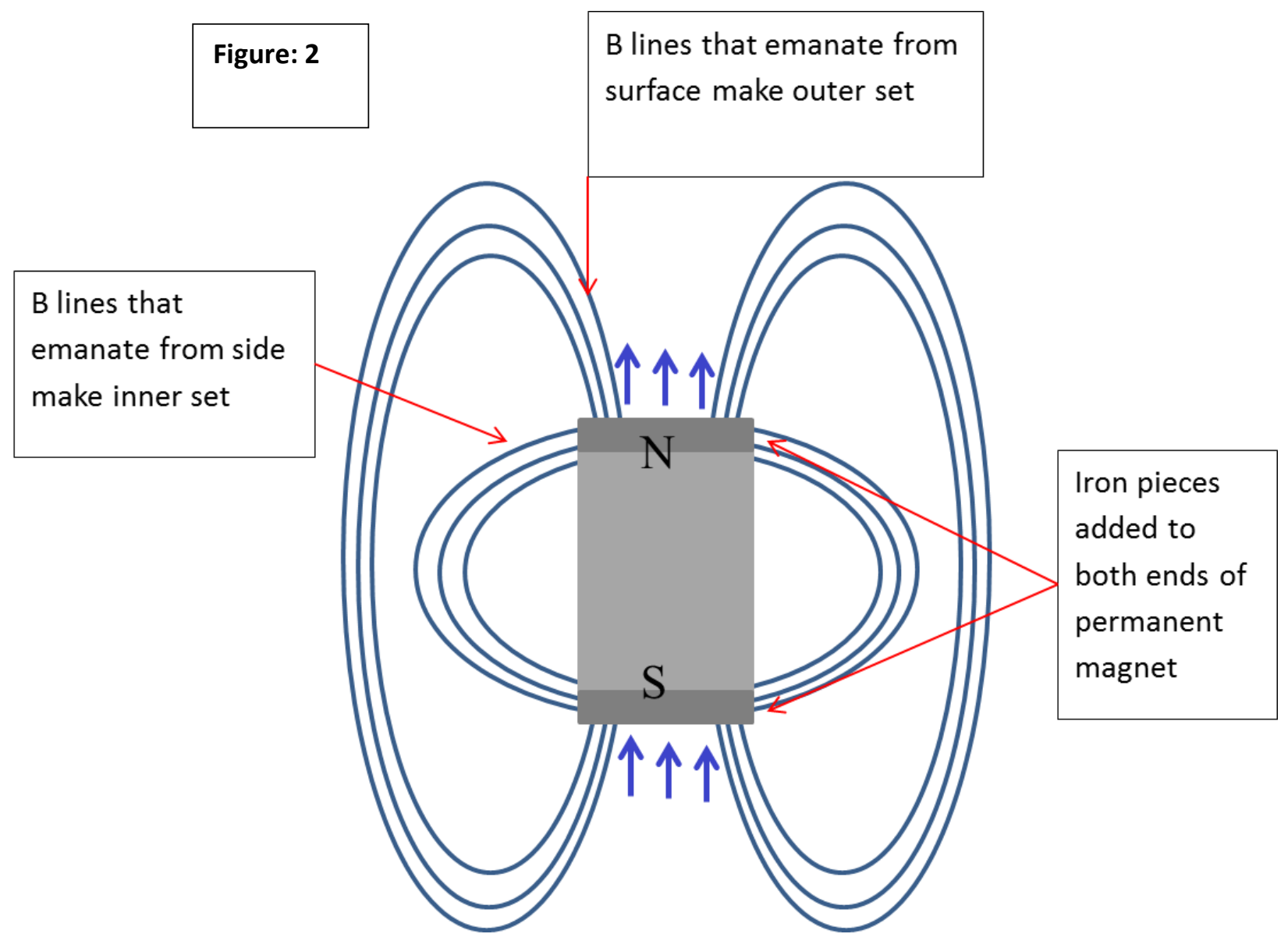


3. Measurement of the B lines using a gauss meter

- A gauss meter can measure only strength of outer set of $B$ lines of a permeable permanent magnet.

- Inner set of B lines remains hidden and is activated only when the magnet attracts another magnet.

- That is why a gauss meter cannot read the real strength of a permeable permanent magnet.

- Figure is given bellow.

Figure: 3

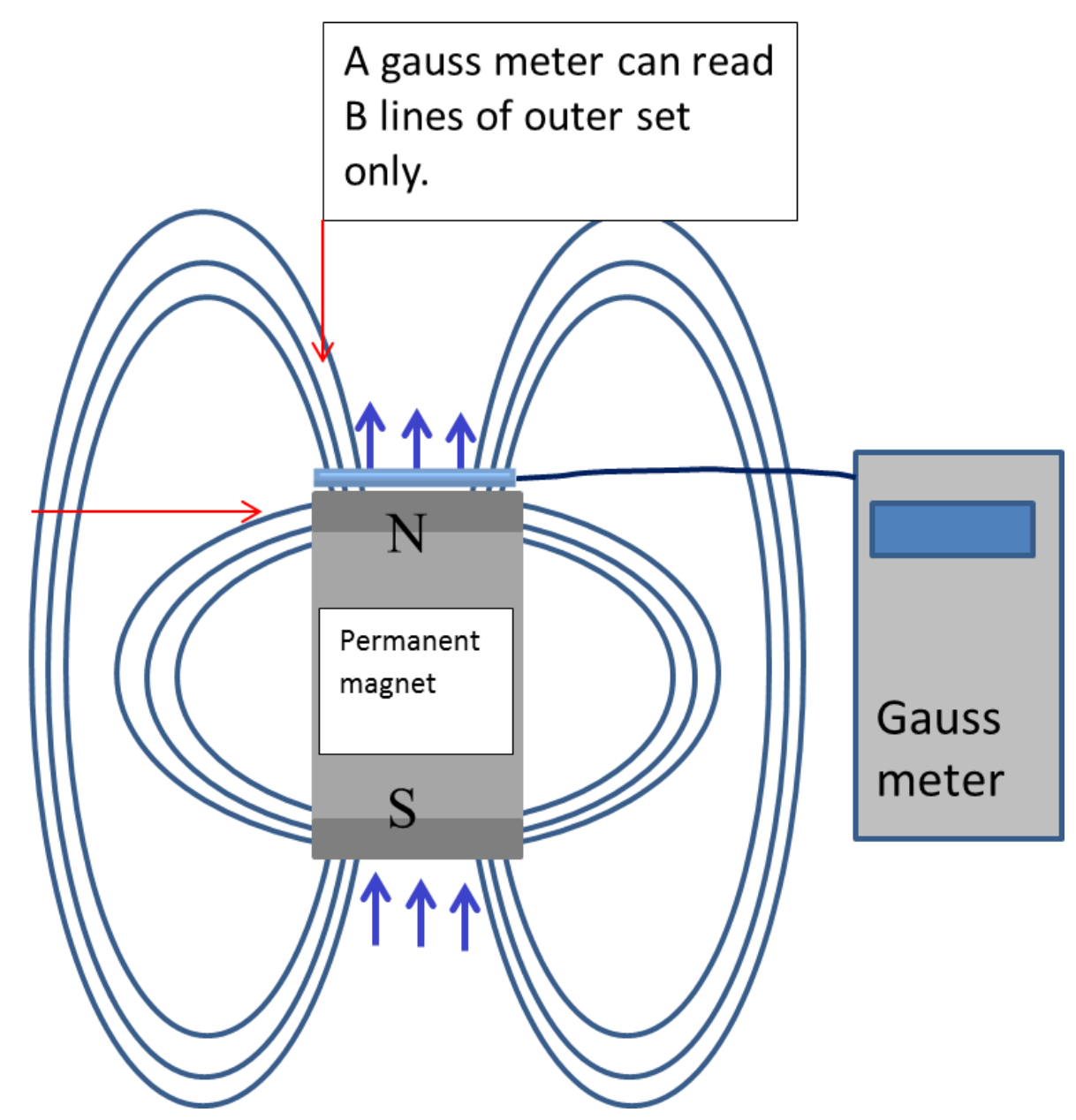

A gauss meter cannot read B lines of inner set because of direction of the flux lines. 
4. Attraction between a permeable permanent magnet and iron

- Contrary to an ordinary permanent magnet of same strength, a permeable permanent magnet attracts an iron piece weakly.

- Inner set of B lines ignores the iron piece and go on making loop with other pole.

- Only outer set of B lines attracts the iron piece.

- Figure is given bellow.

Figure: 4

Outer set of B lines is attracting iron piece

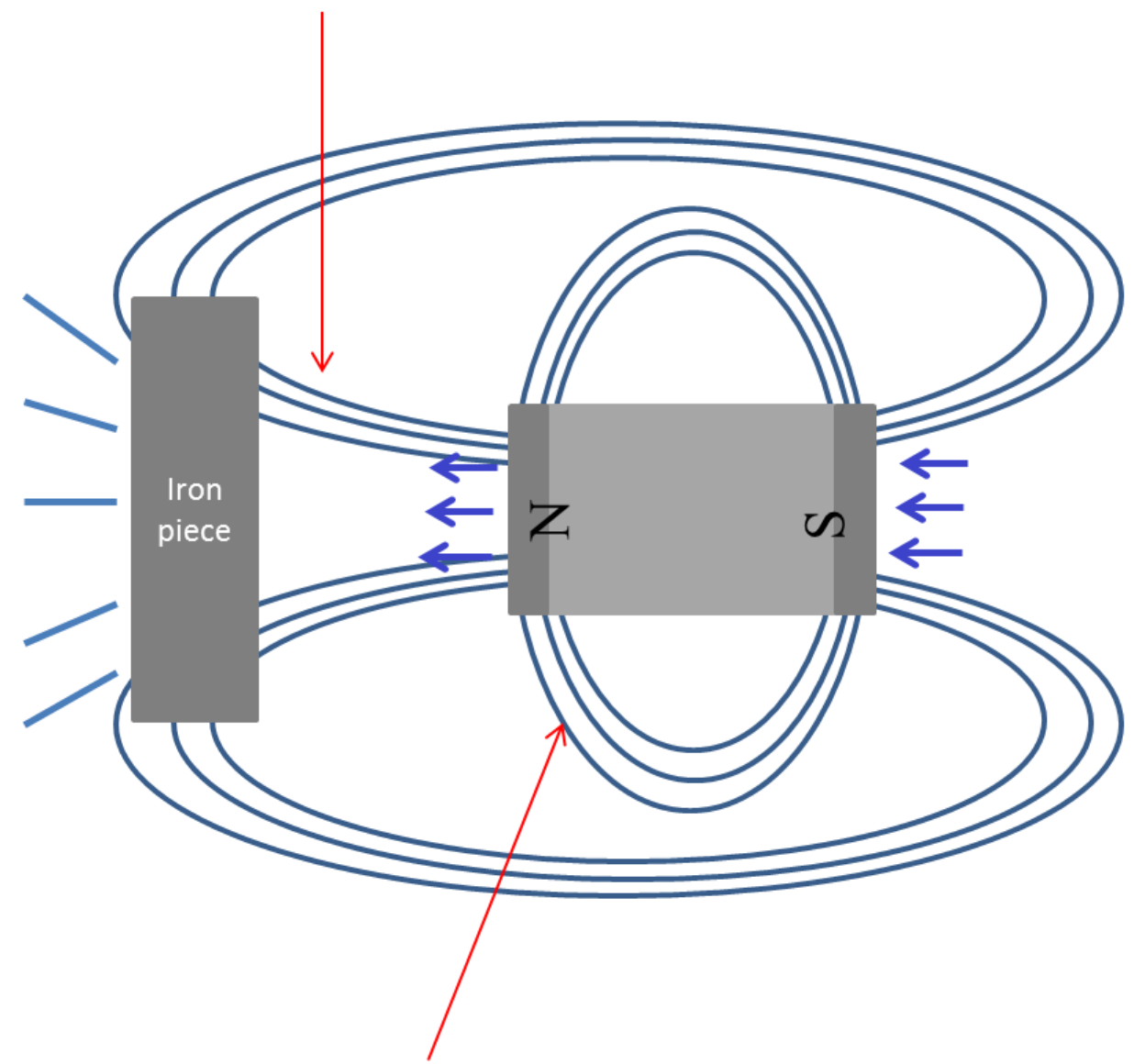

Inner set of B lines is making loop, heedless of iron. 
5. Attraction between a permeable permanent magnet and an electromagnet magnet

- Attraction force of a permeable permanent magnet remains same as that of an ordinary permanent magnet.

- Inner set of flux lines ceases to exist due to presence of unlike pole on opposite side.

- All B lines follow attraction. So, full attraction force of a permeable permanent magnet is got.

- Figure is given bellow.

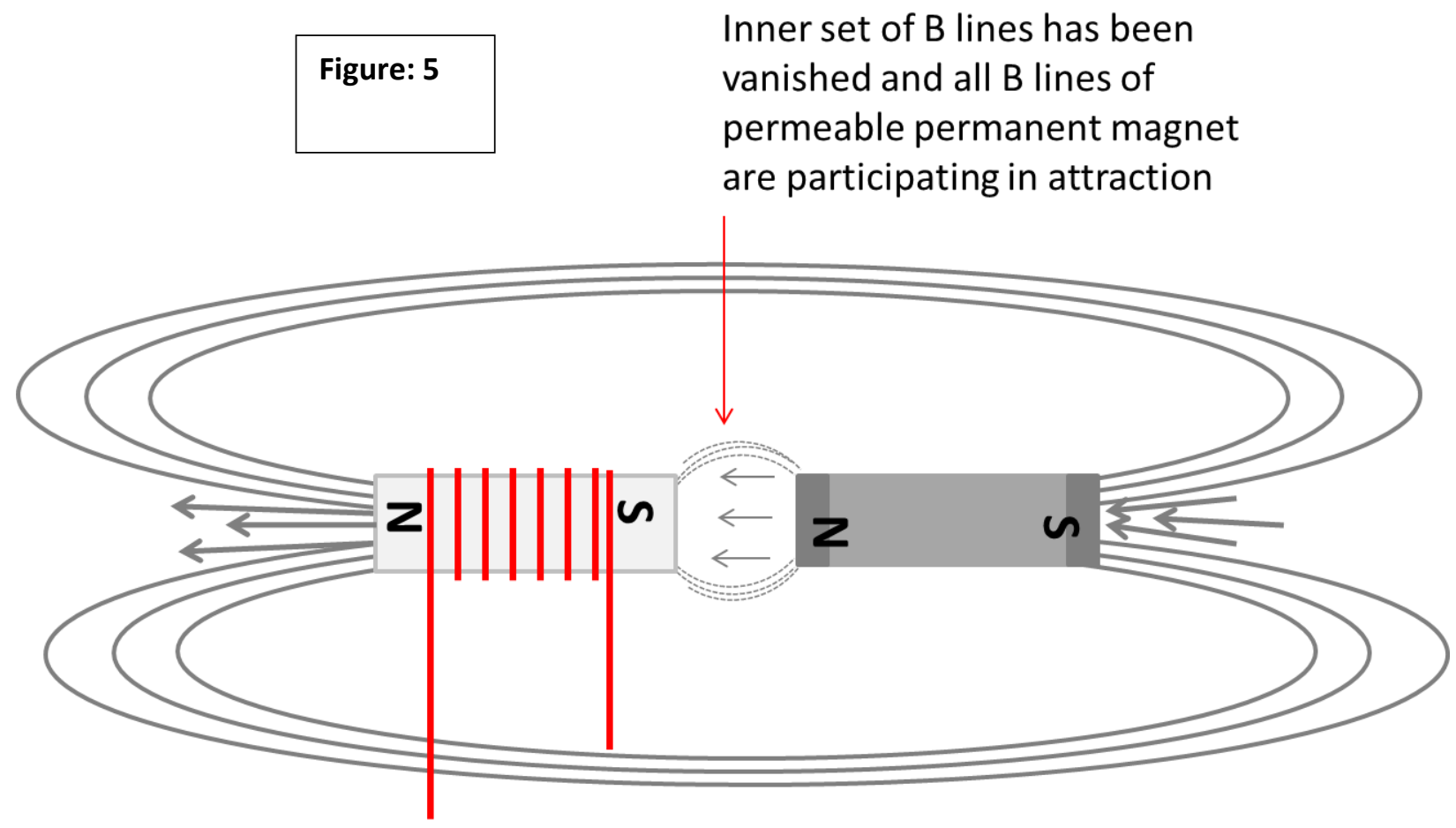


6. Repulsion between an ordinary permanent magnet and an electromagnet

- When an ordinary permanent magnet repels a nonsaturated electromagnet, some of its flux repels the flux of the electromagnet; some of PM flux penetrates into iron and attracts it, instead of repelling.

- This attraction force balances equal part of repulsion force.

- Repulsion force is damaged ultimately.

- Figure is given bellow.

Figure: 6

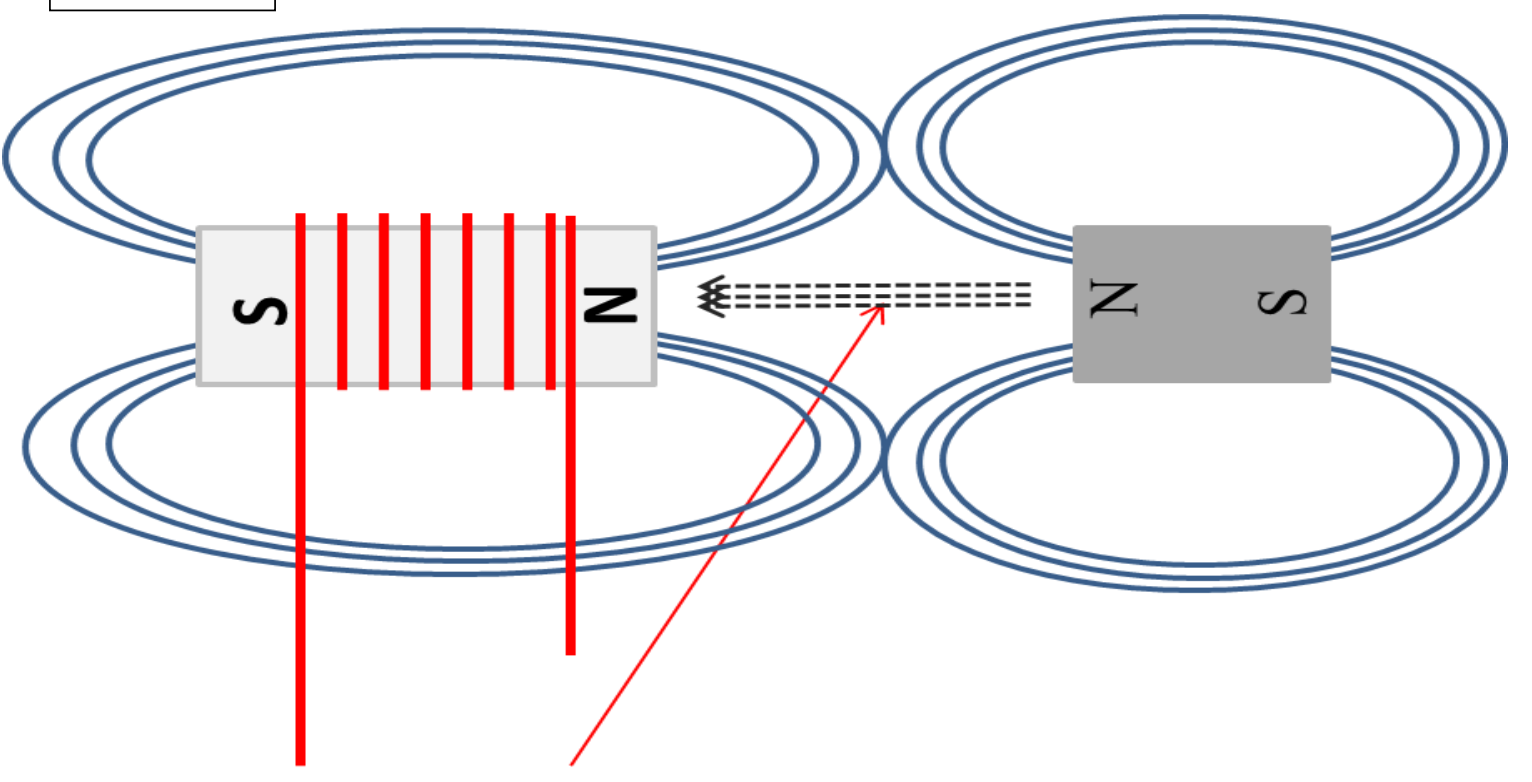

Flux of ordinary permanent magnet is penetrating into iron of electromagnet during repulsion 
7. Repulsion between a permeable permanent magnet and an electromagnet

- When a permeable permanent magnet repels an electromagnet, some of its flux repels the flux of the electromagnet.

- Some of its flux emits from sides of iron piece to avoid confrontation to the like flux of the electromagnet.

- Only a smaller quantity of flux remains available to penetrate into the electromagnet.

- Weak penetration of PM flux into iron of the electromagnet produces weak attraction only.

- Weak attraction balances smaller part of repulsion force.

- So, repulsion force of permeable permanent magnet is always stronger than that of an ordinary permanent magnet.

- Figure is given bellow.

Inner set of B lines is making loop with its other pole, avoiding confrontation with opposite like pole.

Figure: 7

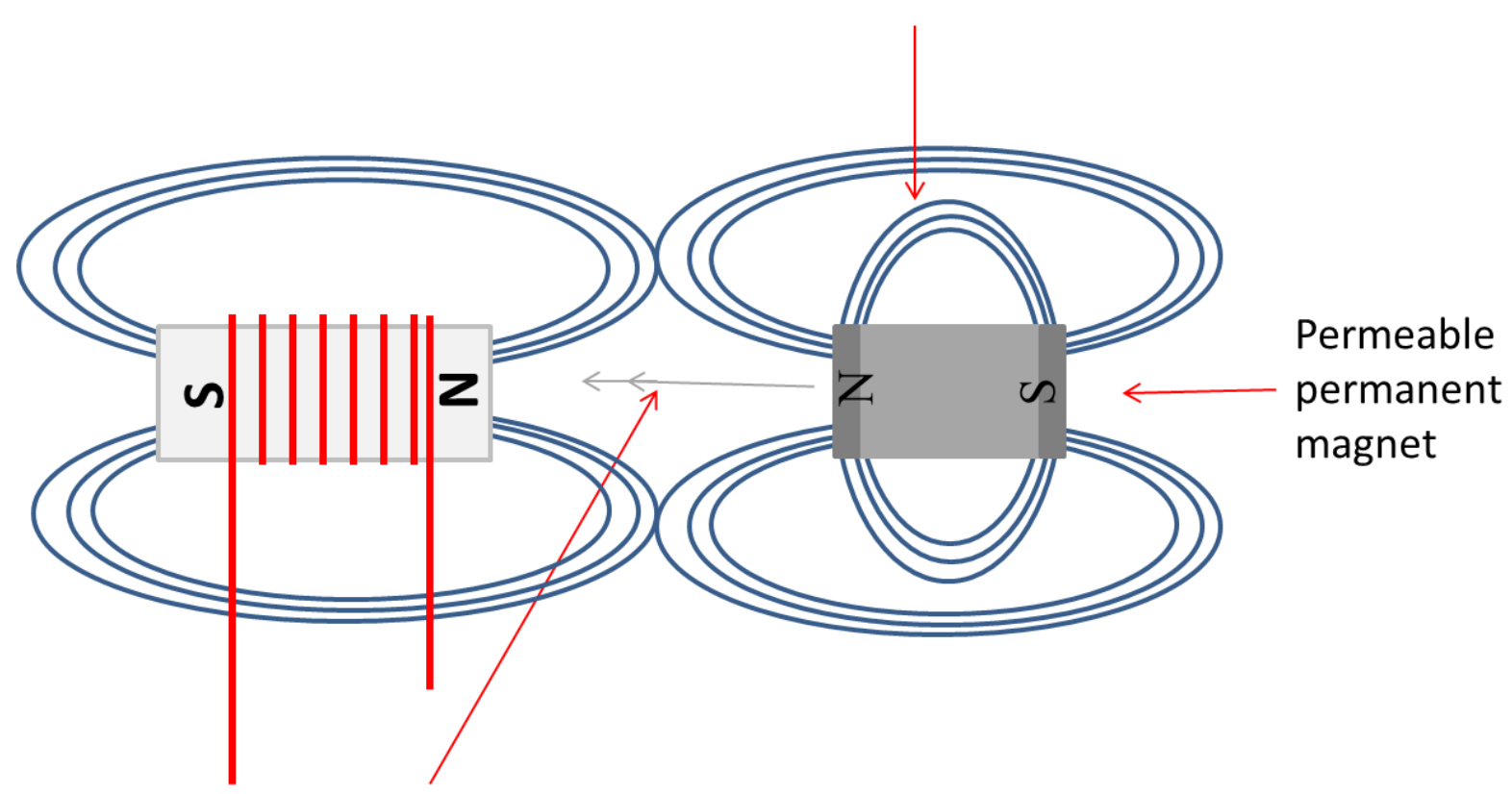

A smaller amount of B lines of outer set is available to penetrate into the iron of electromagnet during repulsion. 


\section{Result}

When interacting with an unsaturated electromagnet:

- Attraction force of a permeable permanent magnet is always the same as that of an ordinary permanent magnet of the same strength.

- Repulsion force of a permeable permanent magnet is always reasonably stronger than that of an ordinary permanent magnet of the same strength.

\section{Alternative design of permeable permanent magnet}

To make closed loops, B lines do not need to emit from surface of a magnet necessary. B lines can make closed loop outside a magnet instead of reaching the surface if these find a short path through weak parts of a magnet. B lines will form closed loops not just through outside but also through weaker regions of the magnets themselves.

It is apparent that if a piece of a magnetic material is added to a pole of a permanent magnet, the piece will become a weaker part of the magnet. So, a reasonable amount of $B$ lines will find a regular scope to emit before reaching the surface.

Presence of non- magnetized parts in a magnet provides extra permeability to $B$ lines. Extra permeability provides scope for $B$ lines to choose best path to make loop and to choose best way to express maximum range of their inherent properties.

All this means that adding of extra iron or any other material is not must. A non- saturated magnet can act like a high repulsion permanent magnet, too. Figure:

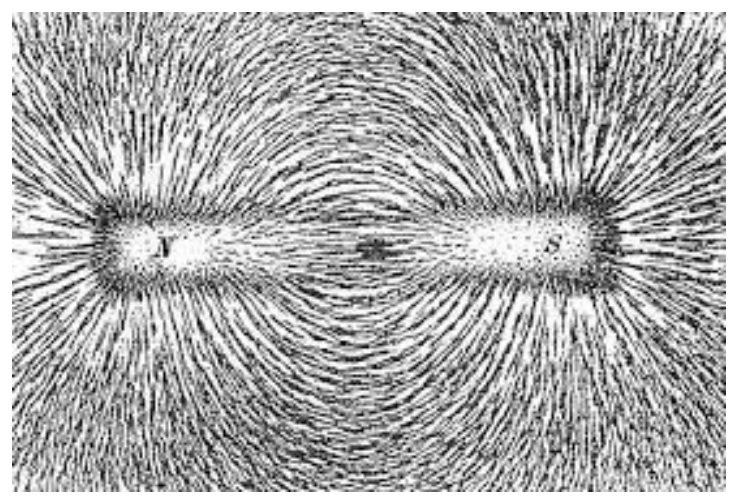

Picture from Google search 


\section{Experiments}

3 real experiments were conducted to verify the function of $B$ lines of permeable permanent magnet. Numbers allotted to these experiments are 4, 5 and 6; because these experiments have to be compared with the results of previous experiments (paper 1 of 7).

- These experiments were conducted using the same methods and the same devices that were used to conduct the previous experiments (in paper 1 of 7: 'Basic research; emerging of extra efficiency' ). Only saturated permanent magnet was replaced by permeable permanent magnet.

- To make a permeable permanent magnet the same permanent magnets were used as were used in previous experiments.

- To make a permeable magnet for each of these experiments, a nonmagnetized piece of magnetic material was added to required number of permanent magnets.

- Specification of the piece= ring shape, grade SH33 (material), size: $\mathrm{D} 25 \mathrm{~mm} * \mathrm{~d} 12 \mathrm{~mm} * 2 \mathrm{~mm}$.

- The same electromagnet interacted with permeable permanent magnet on a magnetic power measuring device. Specification of the device has been given in paper 1 of 7 .

- In each of these three experiments, the electromagnet and permeable permanent magnet performed three interactions:

- Both of them repelled each other. Data was collected.

- Both of them attracted each other without current. Data was collected.

- Both of them attracted each other with current. Data was collected.

- The same input was used for repulsion and attraction of an experiment.

- Comparison of results of these three experiments with those of previous experiments clearly showed that:

- Permeable permanent magnet provided very high repulsion force at lower current levels in comparison with that of an ordinary magnet. 
Magnetic configuration in experiment number 4:

- All data of this experiment has been given in data table number 4 .

- Two permanent magnets were used with the non-magnetized piece.

- Situation of interacting electromagnet and permeable permanent magnet:

\section{Electromagnet}

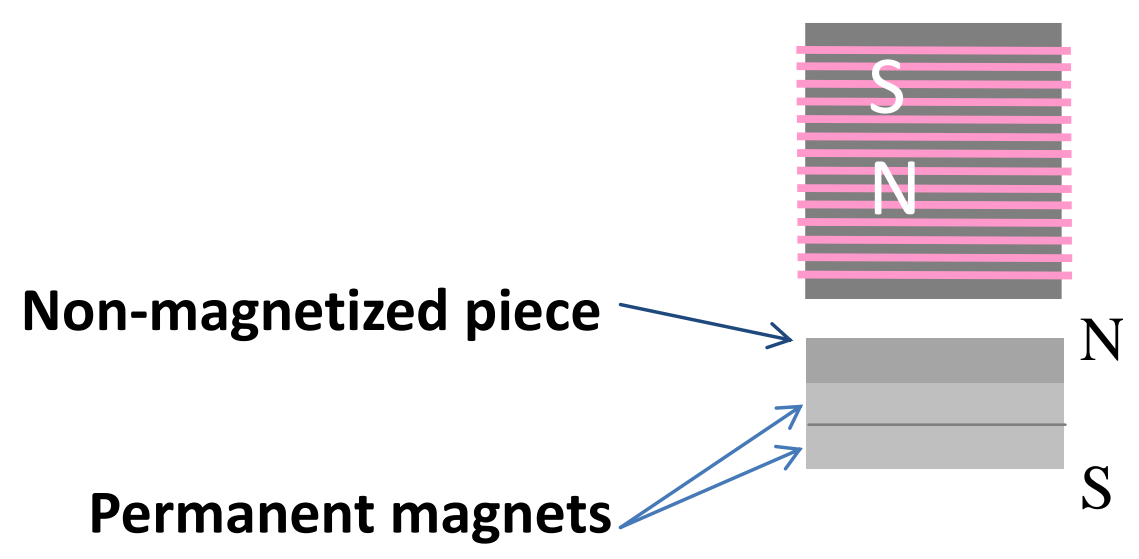

Magnetic configuration in experiment number 5:

- All data of this experiment has been given in data table number, 5 .

- Three permanent magnets were used with the non-magnetized piece.

- Situation of interacting electromagnet and permeable permanent magnet:

\section{Electromagnet}

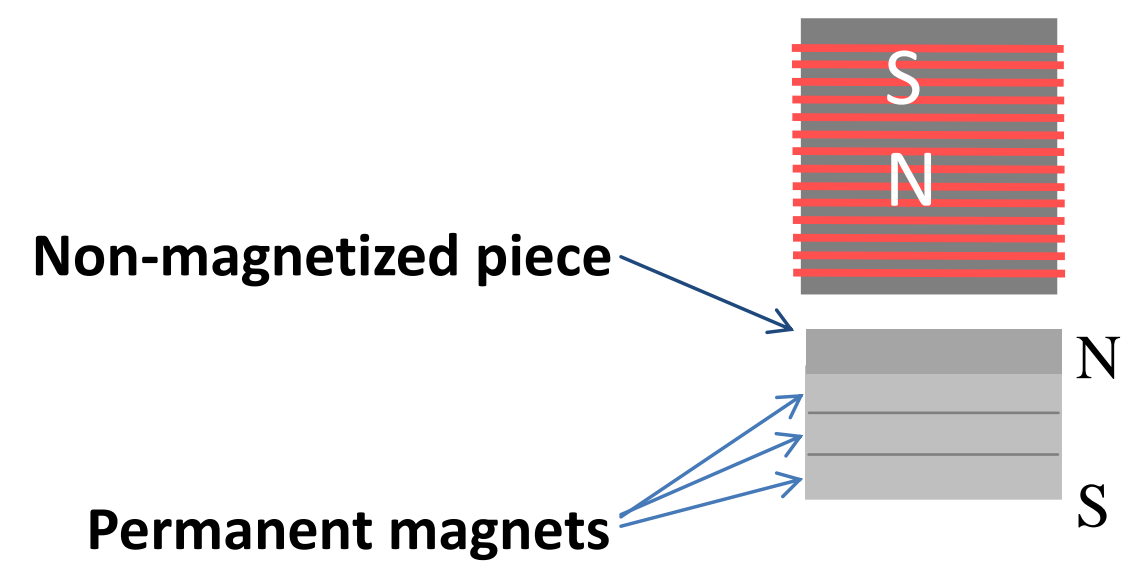


Magnetic configuration in experiment number 6:

- $\quad$ All data of this experiment has been given in data table number, 6 .

- $\quad$ Four permanent magnets were used with the non-magnetized piece.

- Situation of interacting electromagnet and permeable permanent magnet:

\section{Electromagnet}

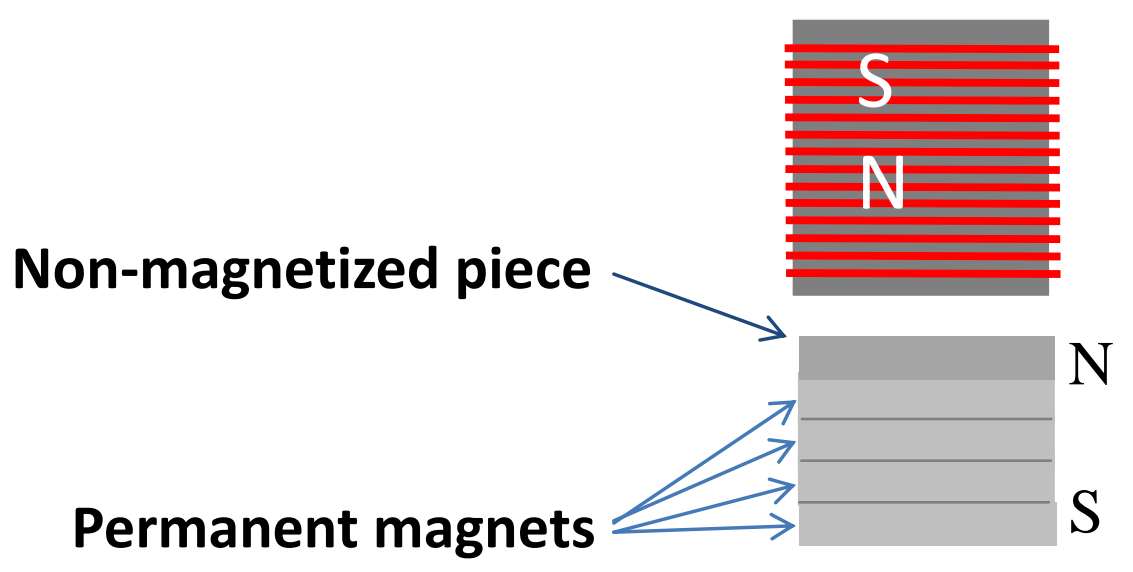

Combined result of experiments numbers 4 to 6.

During all these three experiments, B lines emanated in accordance with the pattern number, 7 of $B$ line description. The same patron is given bellow for reminding.

Inner set of B lines is making loop with its other pole, avoiding confrontation with opposite like pole.

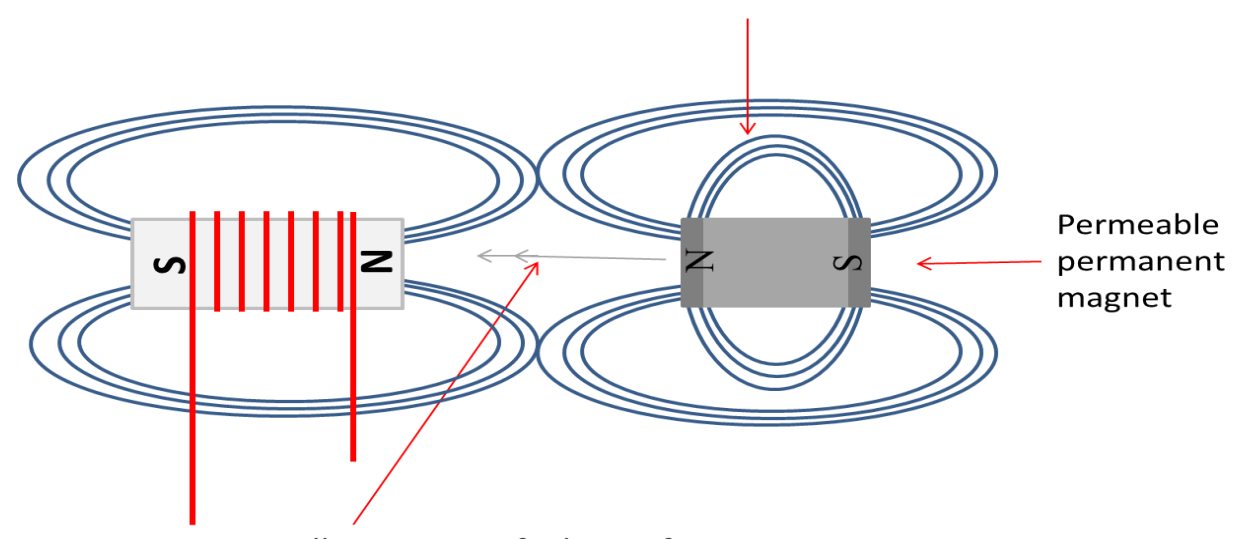

A smaller amount of B lines of outer set is available to penetrate into the iron of electromagnet during repulsion. 


\section{Combined functions of all the three experiments conducted on permeable}

\section{permanent magnet}

- Permeable permanent magnet allowed a reasonable part of its B lines to escape from the edges to avoid like flux of electromagnet.

- A smaller part of B lines remained available to emanate from surface.

- A large part of surface $B$ lines repelled like flux of electromagnet.

- At the end, a small number of $B$ lines of permeable magnet remained available to penetrate into the iron-core.

- Smaller number of B lines produced very weak 'attraction during repulsion'.

- Very weak attraction during repulsion balanced only a little amount of repulsion force.

- Size of balanced (cancelled) force reduced highly. Resultant force increased reasonably. Efficiency increased greatly.

- Repulsion forces of these three experiments are approximately 53\% greater than those of previous experiments numbers 1 to 3 .

- Higher repulsion allowed using of higher flux of permanent magnet. Higher flux provided higher attraction force during a complete cycle of repulsion an attraction. Higher attraction produced higher output power.

Table 1: Comparison of efficiencies of saturated and permeable permanent magnets while current was used for both attraction and repulsion

- Experiment numbers 4,5 and 6 used lower input and provided stronger repulsion force in comparison with experiment numbers 1, 2 and 3.

- Experiment numbers 4, 5 and 6 used lower input and provided stronger output of a complete cycle of attraction and repulsion

- Results of experiment number 6 did not prove proper increment in efficiencies. It was only because non-magnetic piece of the material is not thick enough to provide enough scope for $B$ lines to emanate from sides properly. 


\begin{tabular}{|c|c|c|c|c|c|c|c|c|c|c|}
\hline$\sum_{a}$ & 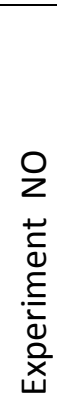 & $\begin{array}{l}\text { Input } \\
\text { Watt- } \\
\text { secon } \\
d \text { for } \\
\text { repul } \\
\text { sion }\end{array}$ & $\begin{array}{l}\text { Outp } \\
\text { ut } \\
\text { repul } \\
\text { sion } \\
\text { powe } \\
r\end{array}$ & $\begin{array}{l}\text { Efficie } \\
\text { ncy of } \\
\text { curre } \\
\text { nt for } \\
\text { repuls } \\
\text { ion }\end{array}$ & $\begin{array}{l}\text { Input } \\
\text { Watt- } \\
\text { secon } \\
d \text { for } \\
\text { attrac } \\
\text { tion }\end{array}$ & $\begin{array}{l}\text { Total } \\
\text { outpu } \\
\mathrm{t} \\
\text { attrac } \\
\text { tion } \\
\text { powe } \\
r\end{array}$ & $\begin{array}{l}\text { Efficie } \\
\text { ncy of } \\
\text { curre } \\
\text { nt for } \\
\text { attrac } \\
\text { tion }\end{array}$ & $\begin{array}{l}\text { Total } \\
\text { input }\end{array}$ & Total output & $\begin{array}{l}\text { Efficiency of } \\
\text { a complete } \\
\text { cycle of } \\
\text { repulsion } \\
\text { and } \\
\text { attraction }\end{array}$ \\
\hline \multirow{3}{*}{ 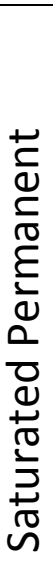 } & 1 & 0.417 & 0.075 & 0.179 & 0.417 & 0.162 & 0.388 & $\begin{array}{l}0.417 * 2 \\
=0.834\end{array}$ & $\begin{array}{l}0.075+0.162 \\
=0.237\end{array}$ & $\begin{array}{l}0.237 / 0.834 \\
=0.284\end{array}$ \\
\hline & 2 & 0.584 & 0.085 & 0.146 & 0.584 & 0.348 & 0.595 & $\begin{array}{l}0.584 * 2= \\
1.169\end{array}$ & $\begin{array}{l}0.085+0.348 \\
=0.434\end{array}$ & $\begin{array}{l}0.434 / 1.169 \\
=0.371\end{array}$ \\
\hline & 3 & 0.646 & 0.100 & 0.154 & 0.646 & 0.610 & 0.944 & $\begin{array}{l}0.646 * 2 \\
=1.292\end{array}$ & $\begin{array}{l}0.100+0.610 \\
=0.710\end{array}$ & $\begin{array}{l}0.710 / 1.292 \\
=0.549\end{array}$ \\
\hline \multirow{3}{*}{ 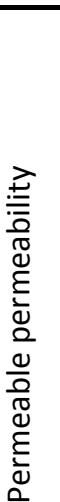 } & 4 & 0.302 & 0.075 & 0.247 & 0.302 & 0.235 & 0.779 & $\begin{array}{l}0.3026 \\
* 2=0.60\end{array}$ & $\begin{array}{l}0.075+0.235 \\
=0.310\end{array}$ & $\begin{array}{l}0.310 / 0.605 \\
=0.513\end{array}$ \\
\hline & 5 & 0.330 & 0.085 & 0.259 & 0.330 & 0.400 & 1.211 & $\begin{array}{l}0.330 * 2 \\
=0.661\end{array}$ & $\begin{array}{l}0.085+0.400 \\
=0.486\end{array}$ & $\begin{array}{l}0.486 / 0.661 \\
=0.735\end{array}$ \\
\hline & 6 & 0.432 & 0.100 & 0.231 & 0.432 & 0.569 & 1.318 & $\begin{array}{l}0.432 * 2 \\
=0.864\end{array}$ & $\begin{array}{l}0.100+0.569 \\
=0.669\end{array}$ & $\begin{array}{l}0.669 / 0.864 \\
=0.775\end{array}$ \\
\hline
\end{tabular}


Table 2. Comparison of efficiencies of saturated and permeable permanent magnets when attraction happened without current

\begin{tabular}{|c|c|c|c|c|c|c|c|}
\hline$\sum_{a}$ & 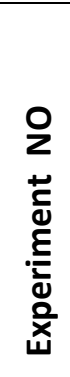 & $\begin{array}{l}\text { Output } \\
\text { attraction } \\
\text { power of } \\
\text { permanent } \\
\text { magnet } \\
\text { only } \\
\text { (without } \\
\text { current) }\end{array}$ & $\begin{array}{l}\text { Input } \\
\text { Watt- } \\
\text { second } \\
\text { for } \\
\text { repulsion }\end{array}$ & $\begin{array}{l}\text { Output } \\
\text { repulsion } \\
\text { power }\end{array}$ & $\begin{array}{l}\text { Efficiency } \\
\text { of } \\
\text { current } \\
\text { for } \\
\text { repulsion }\end{array}$ & Total output & $\begin{array}{l}\text { Efficiency of a } \\
\text { complete cycle } \\
\text { of repulsion and } \\
\text { attraction }\end{array}$ \\
\hline \multirow{3}{*}{ 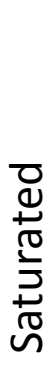 } & 1 & 0.07503 & 0.41736 & 0.07503 & 0.17977 & $\begin{array}{l}0.07503+0.07503 \\
=0.15006\end{array}$ & $\begin{array}{l}0.15006 / 0.41736 \\
=0.35954\end{array}$ \\
\hline & 2 & 0.17675 & 0.58464 & 0.08575 & 0.14667 & $\begin{array}{l}0.17675+0.08575 \\
=0.2625\end{array}$ & $\begin{array}{l}0.2625 / 0.58464 \\
=0.44899\end{array}$ \\
\hline & 3 & 0.31441 & 0.64638 & 0.10004 & 0.15476 & $\begin{array}{l}0.31441+0.10004 \\
=0.41445\end{array}$ & $\begin{array}{l}0.41445 / 0.64638 \\
=0.64118\end{array}$ \\
\hline \multirow{3}{*}{$\begin{array}{l}\frac{0}{0} \\
\frac{0}{0} \\
\frac{d}{0} \\
\frac{d}{0}\end{array}$} & 4 & 0.11331 & 0.30264 & 0.07503 & 0.24791 & $\begin{array}{l}0.11331+0.07503 \\
=0.18834\end{array}$ & \begin{tabular}{|l}
$0.18834 / 0.30264$ \\
$=0.62232$ \\
\end{tabular} \\
\hline & 5 & 0.1995 & 0.33075 & 0.08575 & 0.25925 & $\begin{array}{l}0.1995+0.08575 \\
=0.28525 \\
\end{array}$ & $\begin{array}{l}0.28525 / 0.33075 \\
=0.86243\end{array}$ \\
\hline & 6 & 0.27358 & 0.432 & 0.10004 & 0.23157 & $\begin{array}{l}0.27358+0.10004 \\
=0.37362\end{array}$ & $\begin{array}{l}0.37362 / 0.432 \\
=0.86486\end{array}$ \\
\hline
\end{tabular}

\section{Table 3: Efficiency of current when permeable permanent magnet was used}

- In this method of comparison, output attraction power of permeable permanent magnet has been subtracted and attraction power of only electromagnet is calculated.

- At lower current, permeable permanent magnet showed higher efficiency than that of the saturated permanent magnet. 


\begin{tabular}{|c|c|c|c|c|c|c|c|c|c|c|}
\hline 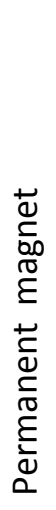 & 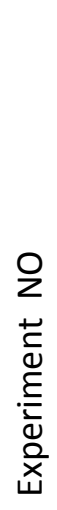 & $\begin{array}{l}\text { Input } \\
\text { Watt } \\
- \\
\text { seco } \\
\text { nd } \\
\text { for } \\
\text { repul } \\
\text { sion }\end{array}$ & $\begin{array}{l}\text { Outp } \\
\text { ut } \\
\text { repul } \\
\text { sion } \\
\text { powe } \\
\text { r }\end{array}$ & $\begin{array}{l}\text { Effici } \\
\text { ency } \\
\text { of } \\
\text { curre } \\
\text { nt for } \\
\text { repul } \\
\text { sion }\end{array}$ & $\begin{array}{l}\text { Input } \\
\text { Watt- } \\
\text { secon } \\
d \text { for } \\
\text { attrac } \\
\text { tion }\end{array}$ & $\begin{array}{l}\text { Outpu } \\
\mathrm{t} \\
\text { attract } \\
\text { ion } \\
\text { power } \\
\text { of } \\
\text { curren } \\
\text { t only }\end{array}$ & $\begin{array}{l}\text { Effici } \\
\text { ency } \\
\text { of } \\
\text { curre } \\
\text { nt } \\
\text { given } \\
\text { for } \\
\text { attrac } \\
\text { tion }\end{array}$ & $\begin{array}{l}\text { Total } \\
\text { input }\end{array}$ & Total output & $\begin{array}{l}\text { Combined } \\
\text { efficiency of } \\
\text { current }\end{array}$ \\
\hline & 1 & $\begin{array}{l}0.41 \\
736\end{array}$ & $\begin{array}{l}0.07 \\
503\end{array}$ & $\begin{array}{l}0.179 \\
77\end{array}$ & $\begin{array}{l}0.417 \\
36\end{array}$ & $\begin{array}{l}0.0872 \\
8125\end{array}$ & $\begin{array}{l}0.209 \\
12\end{array}$ & $\begin{array}{l}0.417 \\
3 * 2= \\
0.834 \\
6\end{array}$ & $\begin{array}{l}0.07503+0.087 \\
28=0.16231\end{array}$ & $\begin{array}{l}0.16231 / 0.834 \\
6=0.19447\end{array}$ \\
\hline & 2 & $\begin{array}{l}0.58 \\
464\end{array}$ & $\begin{array}{l}0.08 \\
575\end{array}$ & $\begin{array}{l}0.146 \\
67\end{array}$ & $\begin{array}{l}0.584 \\
64\end{array}$ & 0.1715 & $\begin{array}{l}0.293 \\
34\end{array}$ & $\begin{array}{l}0.584 \\
6 * 2= \\
1.169 \\
2\end{array}$ & $\begin{array}{l}0.08575+0.171 \\
5=0.25725\end{array}$ & $\begin{array}{l}0.25725 / 1.169 \\
2=0.22002\end{array}$ \\
\hline 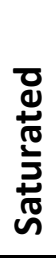 & 3 & $\begin{array}{l}0.64 \\
638\end{array}$ & $\begin{array}{l}0.10 \\
004\end{array}$ & $\begin{array}{l}0.154 \\
76\end{array}$ & $\begin{array}{l}0.646 \\
38\end{array}$ & $\begin{array}{l}0.2960 \\
4\end{array}$ & $\begin{array}{l}0.457 \\
99\end{array}$ & $\begin{array}{l}0.646 \\
3 * 2= \\
1.292 \\
6\end{array}$ & $\begin{array}{l}0.10004+0.296 \\
04=0.39608\end{array}$ & $\begin{array}{l}0.39608 / 1.292 \\
6=0.30642\end{array}$ \\
\hline \multirow{3}{*}{ 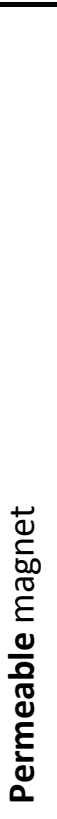 } & 4 & $\begin{array}{l}0.30 \\
264\end{array}$ & $\begin{array}{l}0.07 \\
503\end{array}$ & \begin{tabular}{|l|}
0.247 \\
91
\end{tabular} & $\begin{array}{l}0.302 \\
64\end{array}$ & 0.1225 & \begin{tabular}{|l|}
0.404 \\
77
\end{tabular} & $\begin{array}{l}0.302 \\
6 * 2= \\
0.605 \\
2\end{array}$ & $\begin{array}{l}0.07503+0.122 \\
5=0.19753\end{array}$ & $\begin{array}{l}0.19753 / 0.605 \\
2=0.32638\end{array}$ \\
\hline & 5 & $\begin{array}{l}0.33 \\
075\end{array}$ & $\begin{array}{l}0.08 \\
575\end{array}$ & \begin{tabular}{|l|}
0.259 \\
25
\end{tabular} & $\begin{array}{l}0.330 \\
75\end{array}$ & $\begin{array}{l}0.2012 \\
5\end{array}$ & \begin{tabular}{|l|}
0.608 \\
46
\end{tabular} & $\begin{array}{l}0.330 \\
7 * 2= \\
0.661 \\
4\end{array}$ & $\begin{array}{l}0.08575+0.201 \\
25=0.287\end{array}$ & $\begin{array}{l}0.287 / 0.6614= \\
0.43392\end{array}$ \\
\hline & 6 & $\begin{array}{l}0.43 \\
2\end{array}$ & $\begin{array}{l}0.10 \\
004\end{array}$ & \begin{tabular}{|l|}
0.231 \\
57
\end{tabular} & 0.432 & $\begin{array}{l}0.2960 \\
45\end{array}$ & $\begin{array}{l}0.685 \\
28\end{array}$ & $\begin{array}{l}0.432 \\
* 2= \\
0.864\end{array}$ & $\begin{array}{l}0.10004+0.296 \\
045=0.396085\end{array}$ & $\begin{array}{l}0.396085 / 0.86 \\
4=0.45843\end{array}$ \\
\hline
\end{tabular}




\section{Final conclusions of all three comparisons of functions of both kinds of}

\section{permanent magnet}

If we use the same input for both kinds of permanent magnets and provide enough flux of permeable permanent magnet, while a non- saturated electromagnet is part of the interaction; efficiency of permeable permanent magnet will exceed the efficiency of saturated permanent magnet very highly.

Table: data of experiment 4

\section{Electromagnet: The same}

Permanent magnet: One non-magnetized piece of SH33 and two saturated permanent magnets were added together to become single magnet. The non-magnetized piecewas added on the interacting surface of the magnet.

Steady state resistance $=15$, Provisional mass of actuator $=0.044 \mathrm{~kg}$

Input power applied to interaction of repulsion

\begin{tabular}{|l|l|l|}
\hline $\begin{array}{l}\text { Grass input power applied to the } \\
\text { electromagnet (PeG) }\end{array}$ & Volts*amperes=watts & $16.50^{*} 0.97=16.005$ \\
\hline $\mathrm{I}^{\wedge} 2 \mathrm{R}$ loss (Pr) & le*le *R & $0.97^{*} 0.97 * 15=14.1135$ \\
\hline Net input power (PeN) & PeG $-\mathbf{P r}$ & $16.005-14.1135=1.8915$ \\
\hline Input in watt-second & PeN *time & $1.8915^{*} 0.16=0.30264$ \\
\hline
\end{tabular}

Output power of interaction of repulsion

Mass $=$ Provisional mass of actuator: 0.044 , mass of total load lifted: 0.005 , distance $=0.025 \mathrm{~m}$, time $=0.16 \mathrm{~s}$

\begin{tabular}{l|l|l}
$\begin{array}{l}\text { Output } \\
\text { power }\end{array}$ & $\begin{array}{l}\text { (Provisional mass of Actuator+ mass of load) } \\
* \text { distance/time=Watt }\end{array}$ & $\begin{array}{l}(0.044+0.005) \mathrm{kg} \times 0.025 \mathrm{~m} \times 9.8 \\
\left.\mathrm{~m} / \mathrm{s}^{\wedge} 2\right) / 0.16 \mathrm{~s}=0.07503\end{array}$
\end{tabular}

Input power applied to interaction of attraction

Both interactions of this experiment were conducted on the same input and for the same time.

\begin{tabular}{l|l|l}
\hline Input in watt-second & PeN *time & $1.8915 * 0.16=0.30264$
\end{tabular}

\section{Output power of interaction of attraction}

Total mass lifted by the actuator $=0.110 \mathrm{~kg}$, mass lifted by the actuator without current $=0.30 \mathrm{~kg}$, mass lifted by current $=0.80 \mathrm{~kg}$, distance $=0.025 \mathrm{~m}$, time $=0.16 \mathrm{~s}$

\begin{tabular}{|l|l|l|}
\hline $\begin{array}{l}\text { Total output } \\
\text { power with } \\
\text { current (Pout.I) }\end{array}$ & $\begin{array}{l}\text { (Provisional mass of actuator+ mass of total load } \\
\text { lifted) *distance/time=watt }\end{array}$ & $\begin{array}{l}(0.044+0.110) \mathrm{kg} \times 0.025 \mathrm{~m} \mathrm{x} \\
\left.9.8 \mathrm{~m} / \mathrm{s}^{\wedge} 2\right) / 0.16 \mathrm{~s}=0.23581\end{array}$ \\
\hline $\begin{array}{l}\text { Output power } \\
\text { without } \\
\text { current(Pout.a) }\end{array}$ & $\begin{array}{l}\text { (Provisional mass of actuator+ mass of load lifted } \\
\text { without current)*distance/time=Watt }\end{array}$ & $\begin{array}{l}(0.044+0.030) \mathrm{kg} \times 0.025 \mathrm{~m} \mathrm{~m} \\
\left.9.8 \mathrm{~m} / \mathrm{s}^{\wedge} 2\right) / 0.16 \mathrm{~s}=0.11331\end{array}$ \\
\hline $\begin{array}{l}\text { Output power of } \\
\text { current }\end{array}$ & (Pout.I)- (Pout.a) & $0.2358125-0.1133125=0.1225$ \\
\hline
\end{tabular}


Page 18 of 19

Table: data of experiment 5

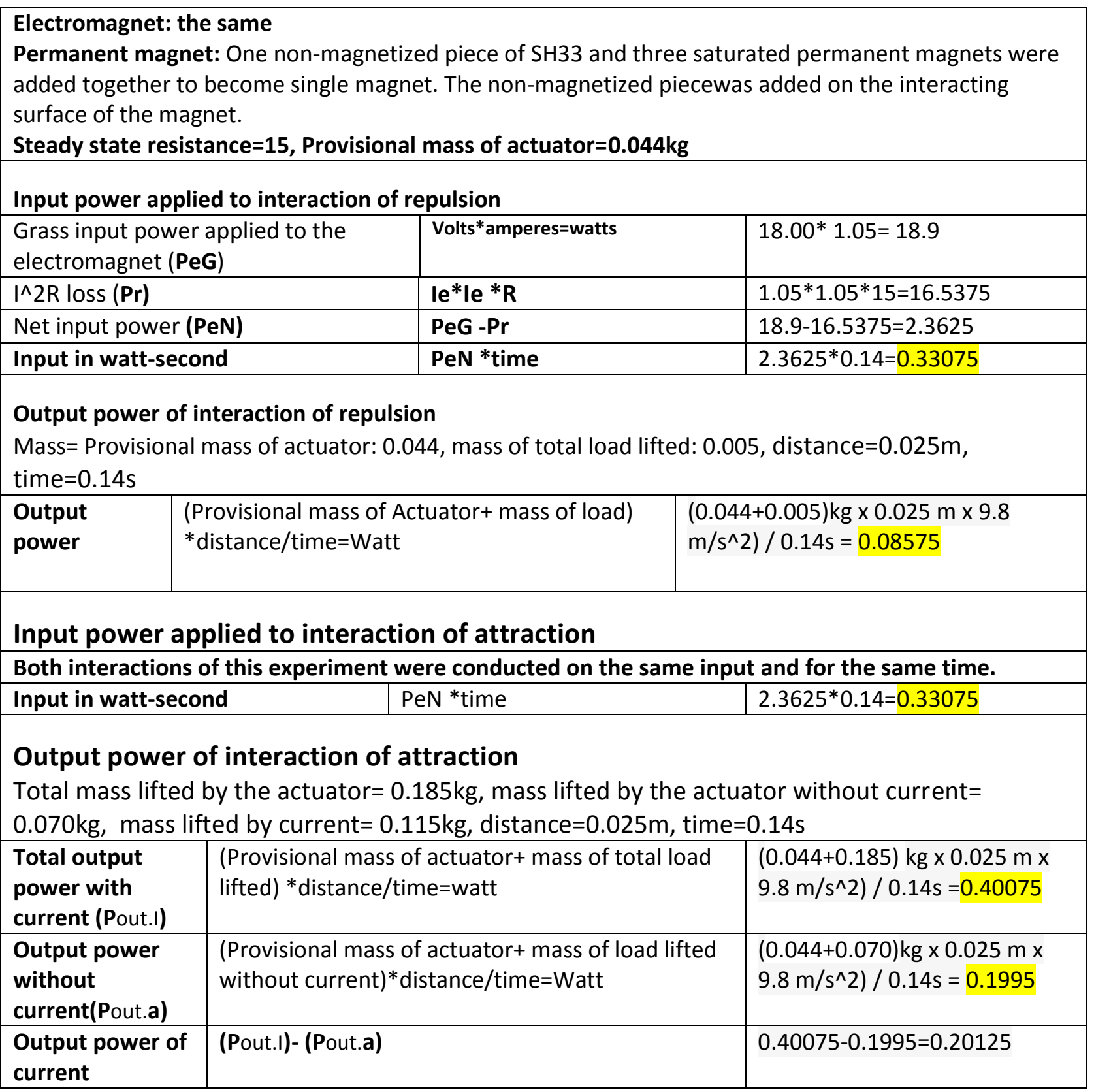


Page 19 of 19

Table: data of experiment 6

\begin{tabular}{|c|c|c|c|c|}
\hline \multicolumn{5}{|c|}{$\begin{array}{l}\text { Electromagnet: the same } \\
\text { Permanent magnet: One non-magnetized piece of } \mathrm{SH} 33 \text { and four sat } \\
\text { added together to become single magnet. The non-magnetized piece } \\
\text { surface of the magnet } \\
\text { Steady state resistance=15, Provisional mass of actuator } \mathbf{0 . 0 4 4 \mathbf { k g }}\end{array}$} \\
\hline \multicolumn{5}{|c|}{ Input power applied to interaction of repulsion } \\
\hline \multicolumn{2}{|c|}{$\begin{array}{l}\text { Grass input power applied to the } \\
\text { electromagnet }(\mathbf{P e G})\end{array}$} & \multicolumn{2}{|l|}{ Volts*amperes=watts } & $21.00 * 1.20=25.2$ \\
\hline \multicolumn{2}{|l|}{ I^2R loss (Pr) } & \multicolumn{2}{|l|}{ le*le * $R$} & $1.20 * 1.20 * 15=21.6$ \\
\hline \multicolumn{2}{|c|}{ Net input power (PeN) } & \multicolumn{2}{|l|}{ PeG -Pr } & $25.2-21.6=3.6$ \\
\hline \multicolumn{2}{|c|}{ Input in watt-second } & \multicolumn{2}{|l|}{ PeN *time } & $3.6 * 0.12=0.432$ \\
\hline \multicolumn{5}{|c|}{$\begin{array}{l}\text { Output power of interaction of repulsion } \\
\text { Mass }=\text { Provisional mass of actuator: } 0.044 \text {, mass of total load lifted: } 0.005 \text {, distance }=0.025 \mathrm{~m} \text {, } \\
\text { time }=0.12 \mathrm{~s}\end{array}$} \\
\hline $\begin{array}{l}\text { Output } \\
\text { power }\end{array}$ & \multicolumn{2}{|c|}{$\begin{array}{l}\text { (Provisional mass of Actuator+ mass of load) } \\
* \text { distance/time }=\text { Watt }\end{array}$} & \multicolumn{2}{|c|}{$\begin{array}{l}(0.044+0.005) \mathrm{kg} \times 0.025 \mathrm{~m} \times 9.8 \\
\left.\mathrm{~m} / \mathrm{s}^{\wedge} 2\right) / 0.12 \mathrm{~s}=0.10004\end{array}$} \\
\hline \multicolumn{5}{|c|}{ Input power applied to interaction of attraction } \\
\hline \multicolumn{5}{|c|}{ Both interactions of this experiment were conducted on the same input and for the same time. } \\
\hline \multicolumn{2}{|c|}{ Input in watt-second } & eN *time & & $3.6 * 0.12=0.432$ \\
\hline \multicolumn{5}{|c|}{$\begin{array}{l}\text { Output power of interaction of attraction } \\
\text { Total mass lifted by the actuator }=0.235 \mathrm{~kg} \text {, mass lifted by the actuator without current }= \\
0.090 \mathrm{~kg} \text {, mass lifted by current }=0.145 \mathrm{~kg} \text {, distance }=0.025 \mathrm{~m} \text {, time }=0.12 \mathrm{~s}\end{array}$} \\
\hline $\begin{array}{l}\text { Total output } \\
\text { power with } \\
\text { current (Pout.I) }\end{array}$ & \multicolumn{3}{|c|}{$\begin{array}{l}\text { (Provisional mass of actuator+ mass of total load } \\
\text { lifted) }{ }^{*} \text { distance/time=watt }\end{array}$} & \begin{tabular}{|l}
$(0.044+0.235) \mathrm{kg} \times 0.025 \mathrm{mx}$ \\
$\left.9.8 \mathrm{~m} / \mathrm{s}^{\wedge} 2\right) / 0.12 \mathrm{~s}=0.569625$
\end{tabular} \\
\hline $\begin{array}{l}\text { Output power } \\
\text { without } \\
\text { current(Pout.a) }\end{array}$ & \multicolumn{3}{|c|}{$\begin{array}{l}\text { (Provisional mass of actuator+ mass of load lifted } \\
\text { without current)* distance/time=Watt }\end{array}$} & $\begin{array}{l}(0.044+0.090) \mathrm{kg} \times 0.025 \mathrm{mx} \\
\left.9.8 \mathrm{~m} / \mathrm{s}^{\wedge} 2\right) / 0.12 \mathrm{~s}=0.27358\end{array}$ \\
\hline $\begin{array}{l}\text { Output power of } \\
\text { current }\end{array}$ & \multicolumn{3}{|c|}{ (Pout.I)- (Pout.a) } & $0.569625-0.27358=0.296045$ \\
\hline
\end{tabular}

Specifications of all components of all these three experiments have been given in paper 1 of 7 